\title{
RTK-GPS を利用した洋上測位システムの開発
}

Development of Marine Surveying System using Real-Time-Kinematic GPS

\author{
古川 敦" 新田 良典 ${ }^{* *}$ 戸上 郁英 ${ }^{* *}$
}

Atsushi Furukawa, Yoshinori Nitta,Ikuhide Tokami

\begin{abstract}
RTK-GPS was applied to positioning of marine construction and the system which enables highly precise and efficient construction management was developed. Although only specific coordinates of 1 point can be obtained at one GPS, in this system the inclination situation of thing can be grasped and made into real time by using three GPSs. By applying this principle to surveying by vessels, highly precise submarine geographical-feature measurement is attained, and highly precise-ization was also checked the accuracy verification by experiment in the real water area.
\end{abstract}

keywords:Survey,GPS(Global Positioning System),SONAR(Sound Navigation and Range)

\section{1.はじめに}

橋梁基礎・防波堤のケーソンや沈埋トンネルの設置時の測位作業には光波測距儀がよく用いられていたが、設置 位置が陸上から遠距離の場合には大がかりな付帯設備が必要となり、雨や濃霧時では測位不可能なため設置作業が できない等の問題があった。

また、海洋工事に関する事前調查、海底掘削や捨石工等の出来形管理において海底地形測量を実施する場合、音 の往復時間から水深を求める精密音響測深機を用いるのが一般的となっているが、この水深值と水平位置との整合 を図るため、従来は陸上からトランシット等で測量船の航行方向を誘導する方法が採られていた。この方法では水 深と水平位置との正確な整合は困難であり、また海底地形を図示するためには煩雑な後処理作業を伴うといった問 題があった。

筆者らは、これらの海洋工事における構造物の位置誘導や海底地形の測量に RTK-GPS(Real-Time-Kinematic Global Positioning System)を利用し、高精度かつその作業を大幅に省力化・効率化できる洋上測位システムの開発を 行ってきた。RTK-GPS を利用した測位システムは従来より種々開発されているが、海洋における地形測量では測 量船が波浪により動摇するため、その測位精度に問題があった。本研究ではGPS 3 基を用い、測位対象物の傾斜・ 動摇が考虑できる高精度かつ簡易なシステムを開発した。開発したシステムは現場適用実験の結果、高精度な測位 性能や実施工への適用性が確認されたため、ここに報告する。

システムは、ケーソンや沈埋トンネルなどの構造物や作業船の位置誘導を行う「海洋構造物位置誘導システム」 と海底地形を高精度に測量する「海底地形測量システム」とで構成するが、本論では「海底地形測量システム」に ついて、その原理および精度について述べることとする。

\section{2.システムの原理}

\section{1 傾斜補正}

RTK-GPS は高精度かつリアルタイムに計測が可能な測量技術である。ただし、GPS 1 基では特定の 1 点の座標 しか得ることができず、測位対象の構造物や船舶等の傾斜状況を把握することはできない。音響測深機を用いた海 底地形測量では、測量船の動摇・傾斜により音響測深センサーが常時鉛直方向を向かず、船位と異なった位置の水 深を計測している(図 2.1.1)。このように GPS1 基により船位を計測した場合、船位と水深の正確な整合ができない ため、測量船の動摇量による測量精度の低下が懸念される。

測位対象物の傾斜(Rolling・Pitching・Yawing)を把握するため、ジャイロや加速度計等を併用したシステムも種々 開発されているが、その取り扱いや機器の応用性等に限定が多い。そこで本研究では、これらの動摇を RTK-GPS 3 基によって特定することとした。

* 正会員 侏熊谷組 技術研究所

** 正会員 侏熊谷組 技術研究所

*** 侏熊谷組 技術研究所 
いま、測位対象物上の点 $p$ の測地座標系での座標值を $x_{p}, y_{p}, z_{p}$ 、測位対象物のワールド座標系での座標值を $x_{p}^{\prime}, y_{p}^{\prime}, z_{p}^{\prime}$ とすると、これらの座標間の関係は式(1)に示すとお りである。

$$
\left(x_{p}, y_{p}, z_{p}\right)=\left(x_{p}^{\prime}, y_{p}^{\prime}, z_{p}^{\prime}\right)\left(\begin{array}{ccc}
l_{1} & m_{1} & n_{1} \\
l_{2} & m_{2} & n_{2} \\
l_{3} & m_{3} & n_{3} \\
x_{0} & y_{0} & z_{0}
\end{array}\right)
$$

$l_{1}, m_{1}, n_{1} ; l_{2}, m_{2}, n_{2} ; l_{3}, m_{3}, n_{3}$ はそれぞれ $x, y, z$ 軸に関する $x^{\prime}, y^{\prime}, z^{\prime}$ 軸の方向余弦であり、上述の測位対象物の傾斜 (Rolling・Pitching・Yawing)に相当する。傾斜状況を考慮した 測位を行うためには、式(1)右項のマトリックスを得る必要 がある。

高精度測位が可能な RTK-GPS を測位対象物(ケーツ・測量船 等)上に 3 基設置することにより測位対象物上の 3 点の測地 座標が求まる。これらの 3 点の座標をもとに、式(2)に示す 式により座標変換マトリックスが求まるため、傾斜を含めた 位置管理が可能となる。

$$
\left(\begin{array}{lll}
l_{1} & m_{1} & n_{1} \\
l_{2} & m_{2} & n_{2} \\
l_{3} & m_{3} & n_{3} \\
x_{0} & y_{0} & z_{0}
\end{array}\right)=\left(\begin{array}{llll}
x_{1}^{\prime}, & y_{1}^{\prime} & z_{1}^{\prime} & 1 \\
x_{2} & y_{2}^{\prime} & z_{2}^{\prime} & 1 \\
x_{3} & y_{3}^{\prime} & z_{3}^{\prime} & 1 \\
A^{\prime} & B^{\prime} & C^{\prime} & 0
\end{array}\right)^{-1}\left(\begin{array}{lll}
x_{1} & y_{1} & z_{1} \\
x_{2} & y_{2} & z_{2} \\
x_{3} & y_{3} & z_{3} \\
A & B & C
\end{array}\right)
$$

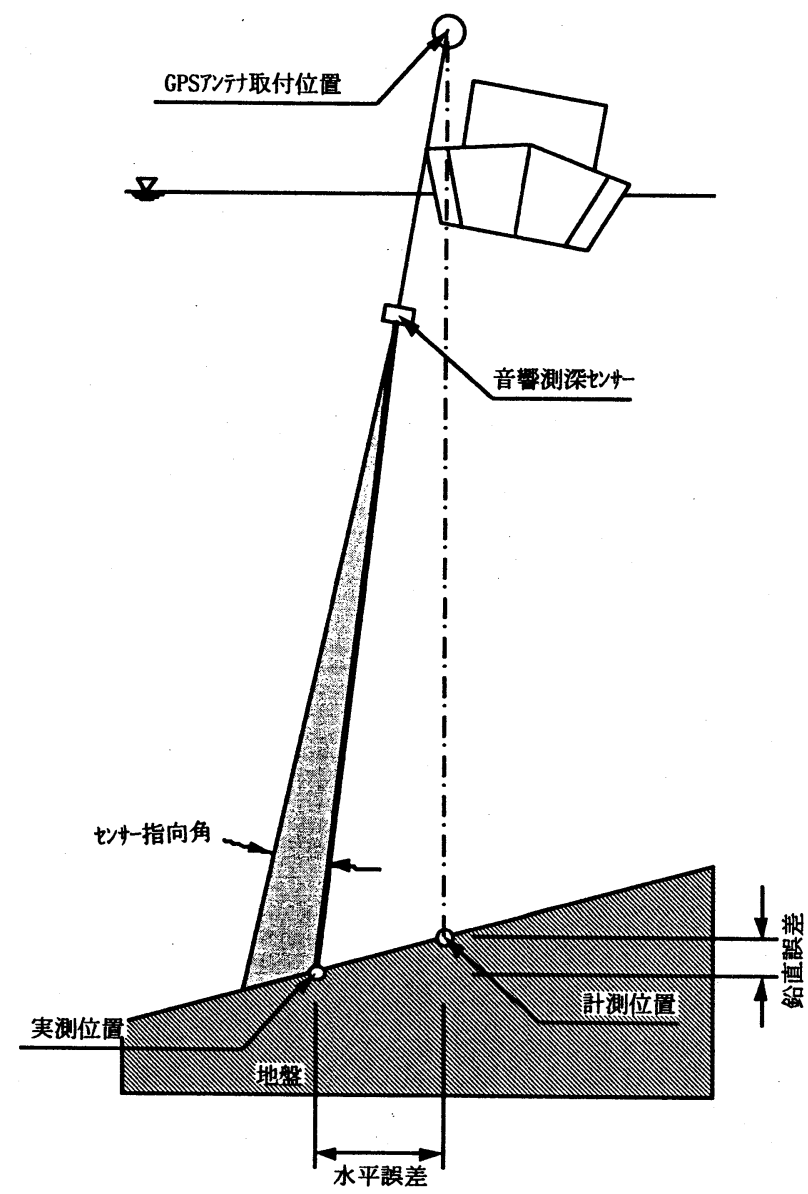

図 2.1.1 船舶の傾斜による計測誤差

$A, B, C$ および $A^{\prime}, B^{\prime}, C^{\prime}$ は $\left(x_{1}, y_{1}, z_{1}\right),\left(x_{2}, y_{2}, z_{2}\right),\left(x_{3}, y_{3}, z_{3}\right)$ の 3 点または $\left(x_{1}^{\prime}, y_{1}^{\prime}, z_{1}^{\prime}\right),\left(x_{2}^{\prime}, y_{2}^{\prime}, z_{2}^{\prime}\right),\left(x_{3}^{\prime}, y_{3}^{\prime}, z_{3}^{\prime}\right)$ の 3 点で決まる平面の法線べクトルを示す。

\section{2 計測機器の同期}

GPS と音響測深機等の計測機器を複 数台用いるため、各機器間の同期が問題 となる。GPS に関しては各衛星に搭載 された原子時計を基淮とした GPS 時間 を測位データと共に出力するため、ソフ トウェアで十分可能である。ただし、こ の GPS 時間に同期した音響測深データ を得るためには音響測深データに GPS 時間と同精度の時計を搭載するか、GPS 受信機側から音響測深機に信号を送り、 この信号と同期した測深結果を出力さ せる、等の工夫が必要となる。

これらの方法では、いずれも音響測 深機や GPS 受信機に専用同期装置なる ハードウェアが必要となる。今回は安価
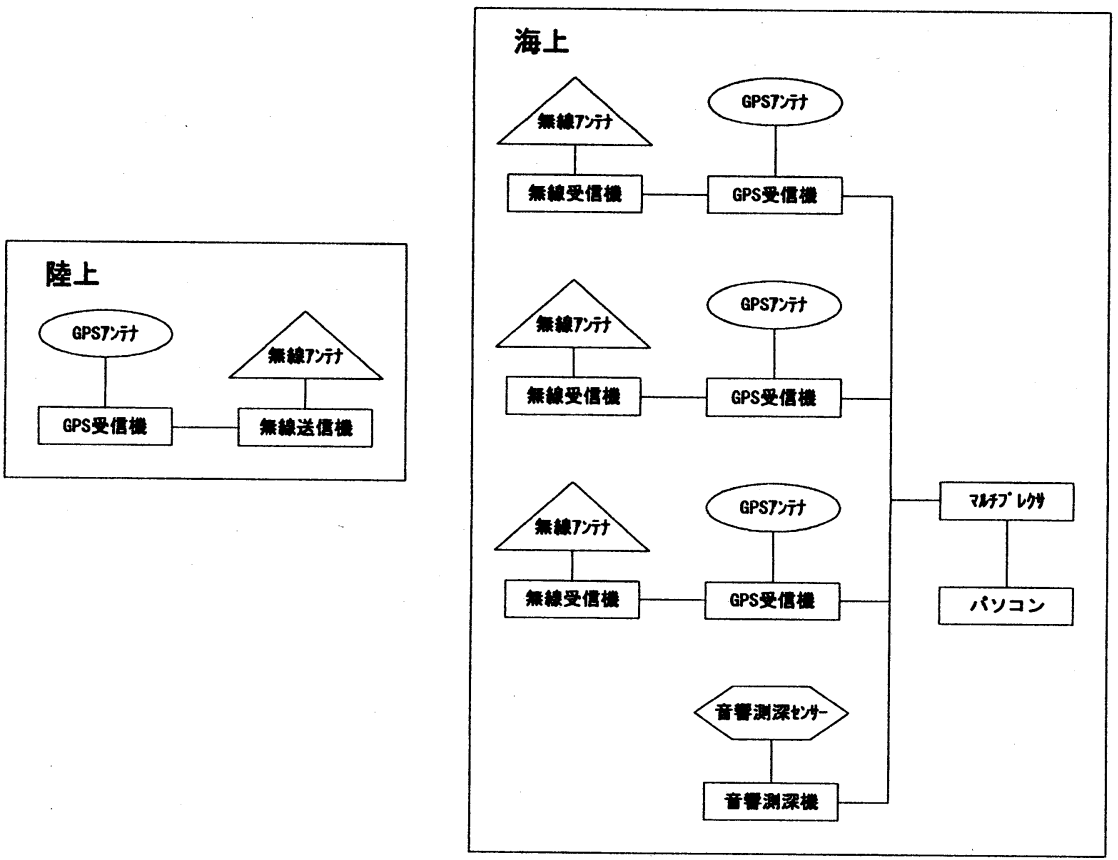

図 2.2.1 システム構成 で簡易なシステムの開発を目標とし、こ 


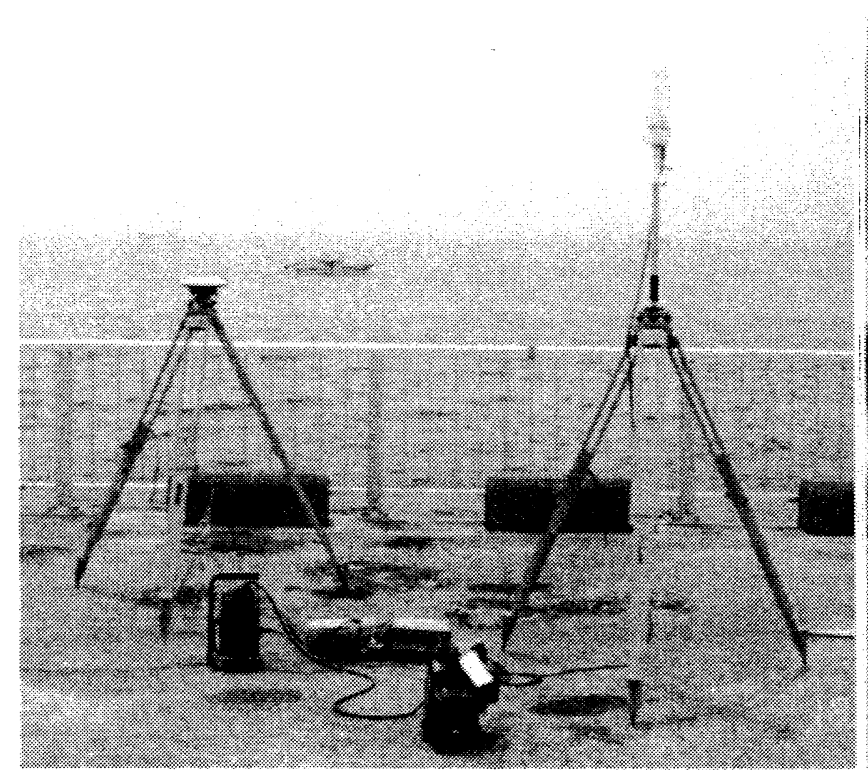

写真 2.2.1 陸上基準局

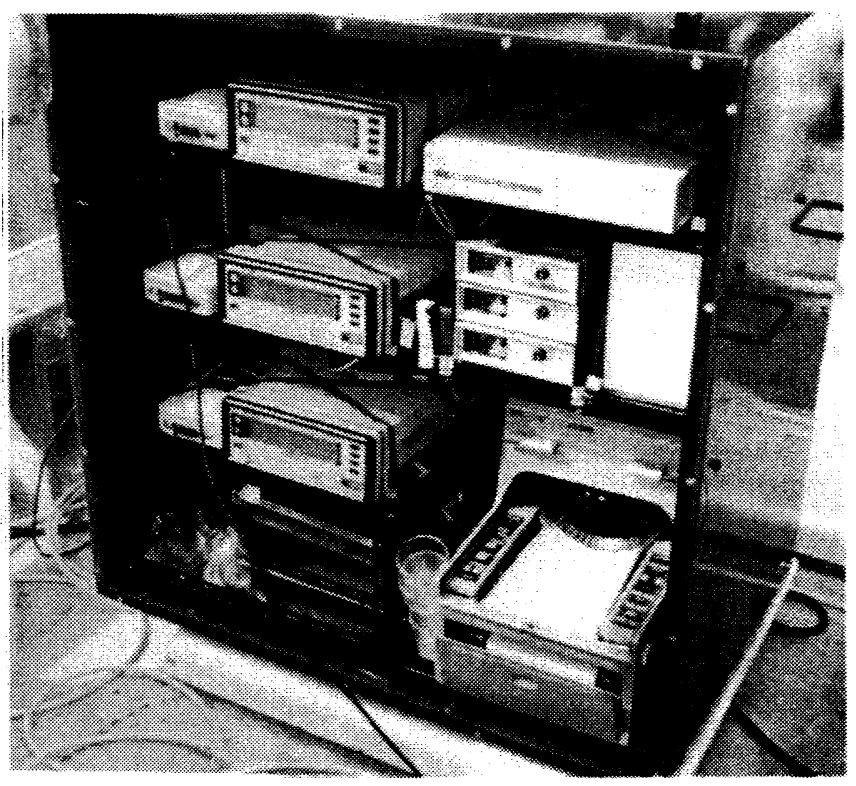
のパソコンモニターを示す。今回は得られた測量点の精 度を検証するのであるが、図からも分かるように測量デ 一タは航跡に依存し、同一のポイントを再計測するため には同一の航跡をたどる必要があり、これは事実上不可 能である。そこで、計測結果の同一水平位置での標高值 のばらつきを評価するため、同一メッシュ上に補間を行 いメッシュ各点毎の標高值のばらつきを算出した。以 下にその手順を示す。

メッシュへの補間方法には様々なものが考えられる が、今回の実験では計測点 1 点毎の精度評価を目的とし ているため、計測点 1 点毎の值を高く反映できる TIN(Triangulated Irregular Network:不定形三角網) モデルにより行うこととした。図 3.2.2に計測結果を元

\section{3.精度検証実験}

本研究では開発したシステムの性能評価を行うため、 以下に示す方法により実水域検証実験を行った。

GPS 3 基による船舶の動摇・傾斜を考慮することに よる精度向上を確認するため、GPS 1 基による場合と の測量精度を比較することとした。実験は香川県府中湖 において $30 \mathrm{~m} \times 30 \mathrm{~m}$ の地形起伏の大きい水域を対象と し、動摇考虑・非考慮の 2 通りの方法による測量を各々 5 回行い、測量結果の再現性（ばらつき）を比較するこ ととした。図 3.1.1に GPS アンテナおよび音響測深セン サ一の配置、写真 3.1.1 にその測量状況を示す。

\section{2 解析方法}

測できる。本実験では船舶を約 $2.5 \mathrm{~m} / \mathrm{sec}$ で航行させるこ とにより、 $30 \mathrm{~m} \times 30 \mathrm{~m}$ の水域を 10 分程度の短時間で、 十分な測量成果を得ることができた。図 3.2.1に測量中
写真 2.2.2 海上使用機器

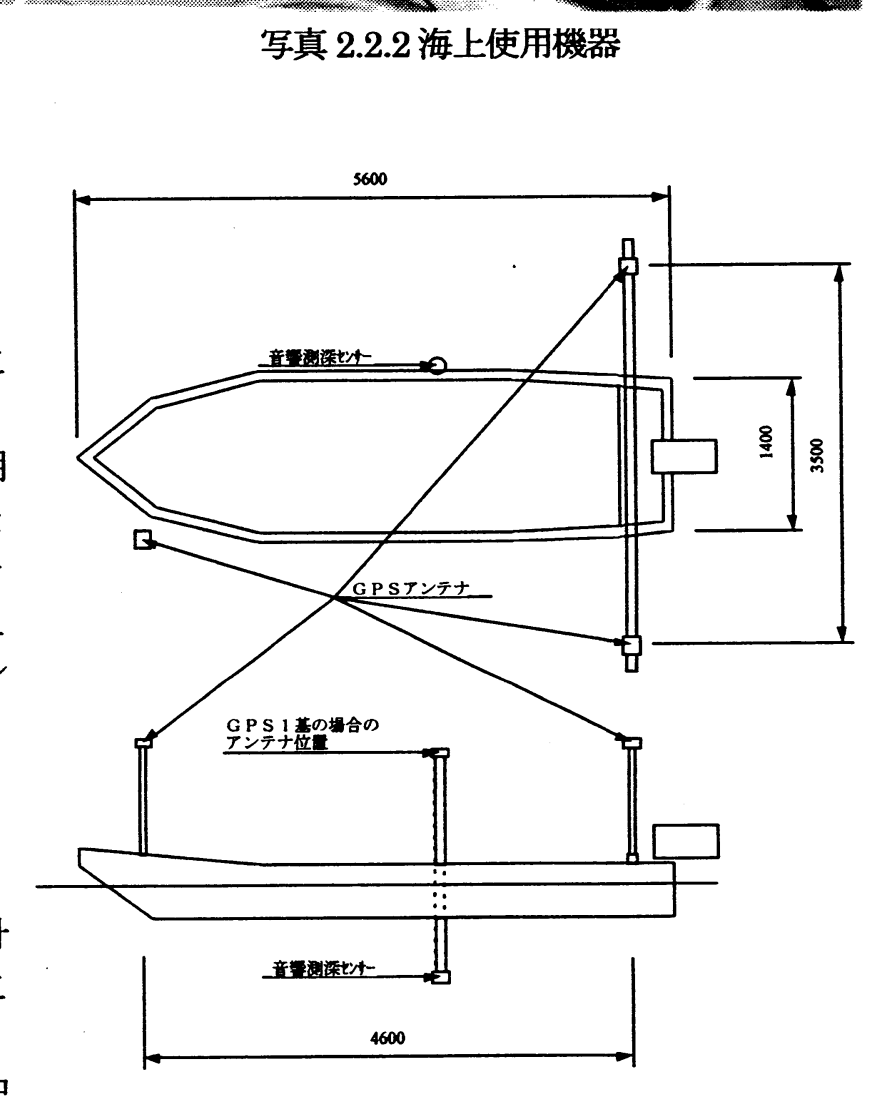

図 3.1.1 G P Sアンテナ配置図

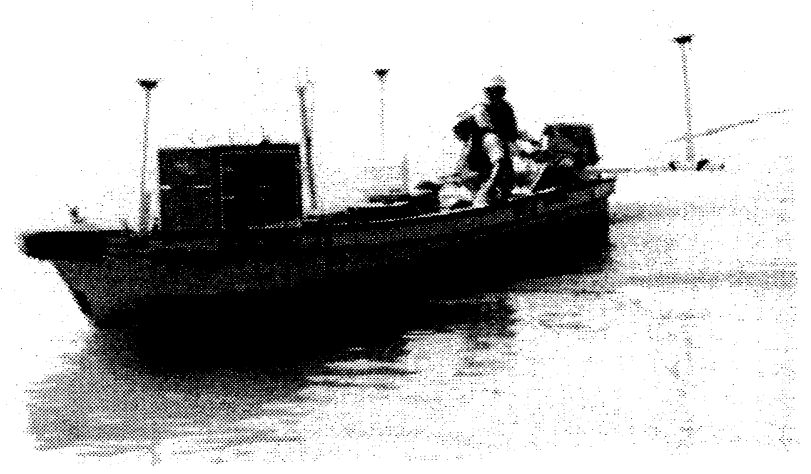

写真 3.1.1 測量状況 
に生成した TIN を示す。図中の三角形の各頂 点は全て得られた計測点を用いている。この TIN を用い、各々の三角形の傾斜角から格子 間隔 $5 \mathrm{~m}$ のメッシュへの補間を行った。図 3.2.3にTIN補間による格子メッシュデータを 用いた等高線図を示す。

\section{3 実験結果}

GPS 1 基および 3 基による計測を各々 5 回 行い、前述の補間を行うことにより各々のメッ シニデータが得られる。解析ではこれら 5 回分 のメッシュデータを各メッシュ交点毎に統計 処理し、3 $\sigma$ を求めた。表 3.3.1 に得られたメ ッシュ標高値、表 3.3.2,3 に GPS 1 基および 3 基の $3 \sigma$ を示す。図 3.3.1 には表 3.3.2,3 を 図化処理した精度分布図を示す。

GPS 1 基での $3 \sigma$ の最大值は $0.43 \mathrm{~m}$ である のに対し、GPS 3 基では $0.31 \mathrm{~m}$ となり、ばら つきが小さくなり精度が向上している(表 3.3.2,3)。また図 3.3.1 の等高線と誤差分布の 対比から分かるように、地形勾配が大きい箇所 において誤差が顕著に現れている。この傾向を、 計測結果のばらつきと地形勾配との関係とし、 図 3.3.2 にまとめた。地形勾配が $10^{\circ}$ 以上に なると GPS 1 基の精度は低下し、GPS 3 基に よる精度改善率は最大で $30 \%$ 以上であった。

今回の実験は波浪の小さな湖であり、測量船 の動摇が少なかったにもかかわらず、GPS 3 基の方が GPS 1 基に比べ測量精度が良いこと が確認された。測量船の動摇の他に、音響測深 機の取り付け状態(傾斜)によっても測量精度 が影響を受けるが、音響測深センサーの取付治 具は、浮遊状態の船舶へ正確に鉛直方向に取り 付けることが困難であり、本実験においても約 $3^{\circ}$ ほど傾斜していることが確認された。GPS 3 基を用いた場合はこの治具の傾斜状況も考 慮できるが、GPS 1 基では常に GPS アンテナ 直下にセンサーが取り付けられていると仮定 し、計測される。水深 $5 \mathrm{~m}$ 、地形勾配 $15^{\circ}$ 、 治具取付誤差 $3^{\circ}$ の条件で GPS 1 基で計測し た場合、予測される計測誤差は約 $165 \mathrm{~mm}$ であ る(図 3.3.3)。この誤差は図 3.3.2 の実測精度差 ともほぼ一致していることからも、治具の傾斜 状態も考慮できる本方式の有効性が実証され た。(なお、図中にも示したが音響測深センサ 一には指向特性があり、指向角範囲内の最も音 波反射率の高い箇所の距離を計測する。）

波浪の大きい海洋においては船舶の動摇も 発生しないため、GPS 1 基では上述の治具取

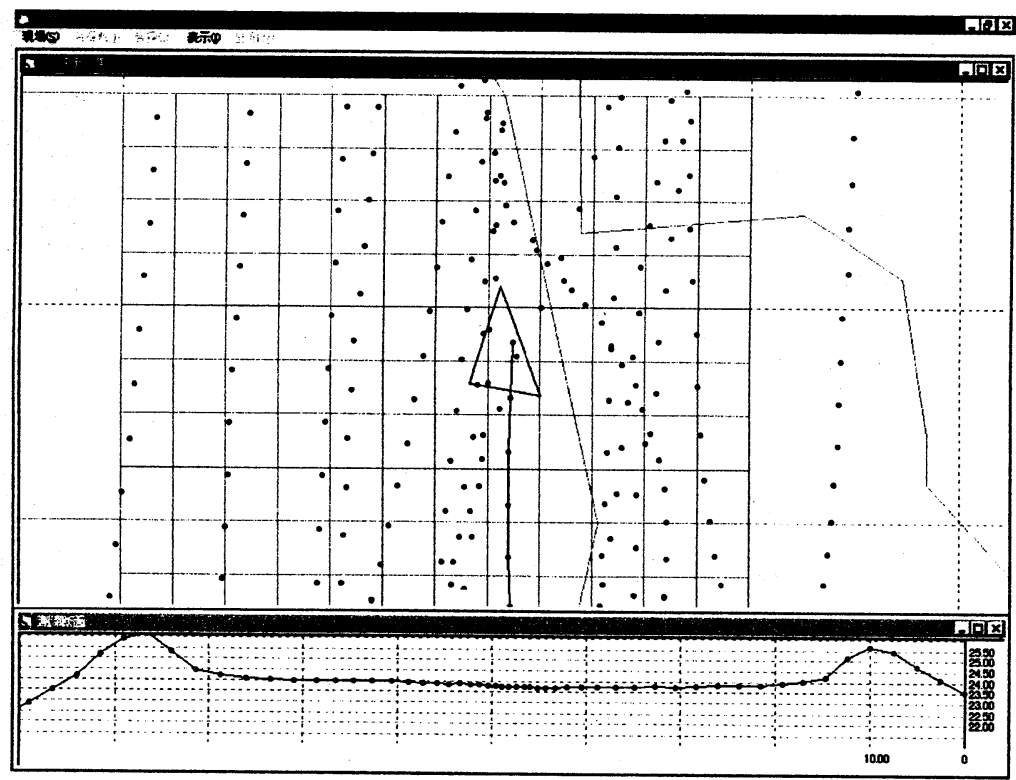

図 3.2.1 測量時モニター(測量点平面図)

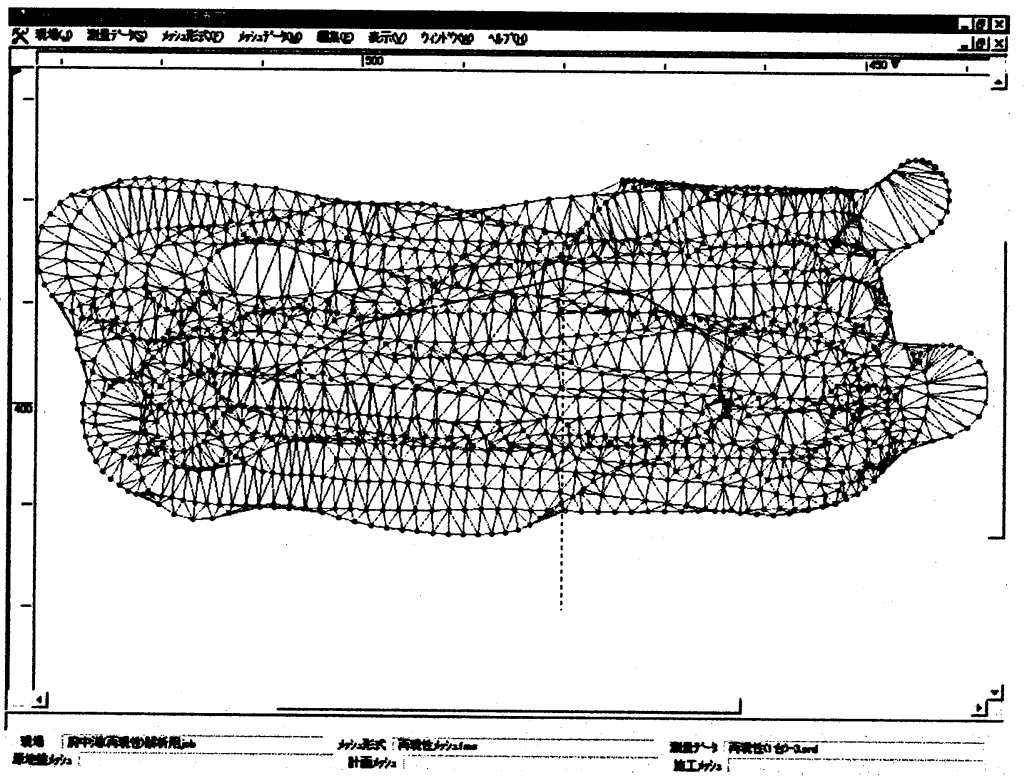

図 3.2.2TIN 生成

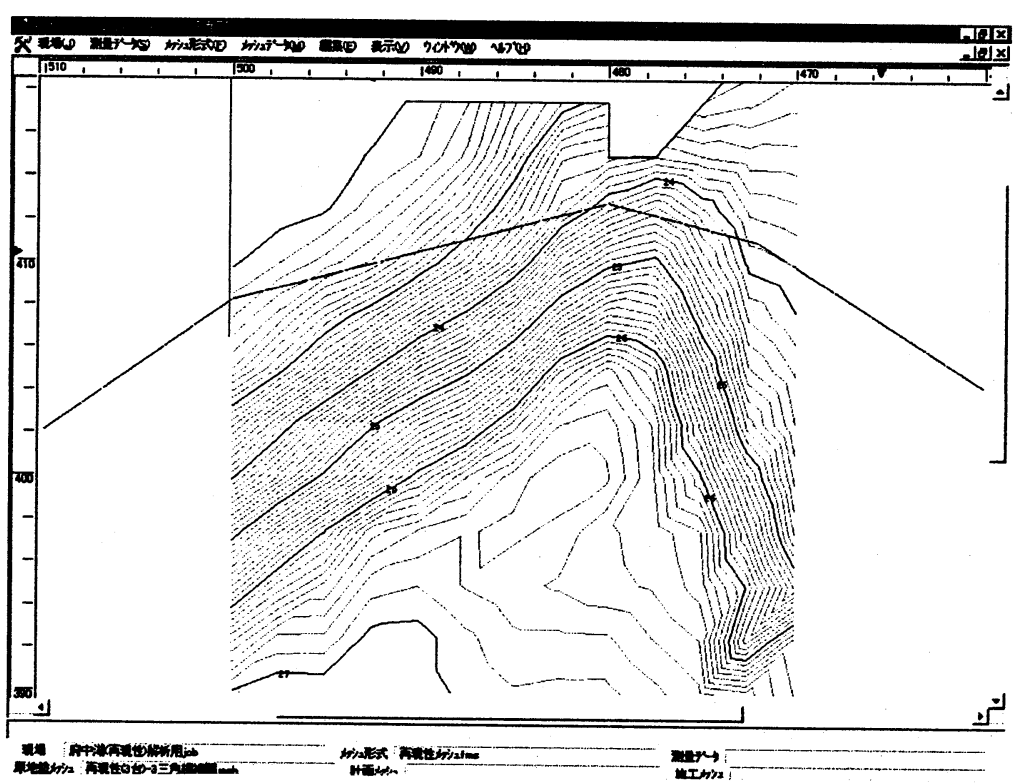

図 3.2.3 メッシュ等高線 


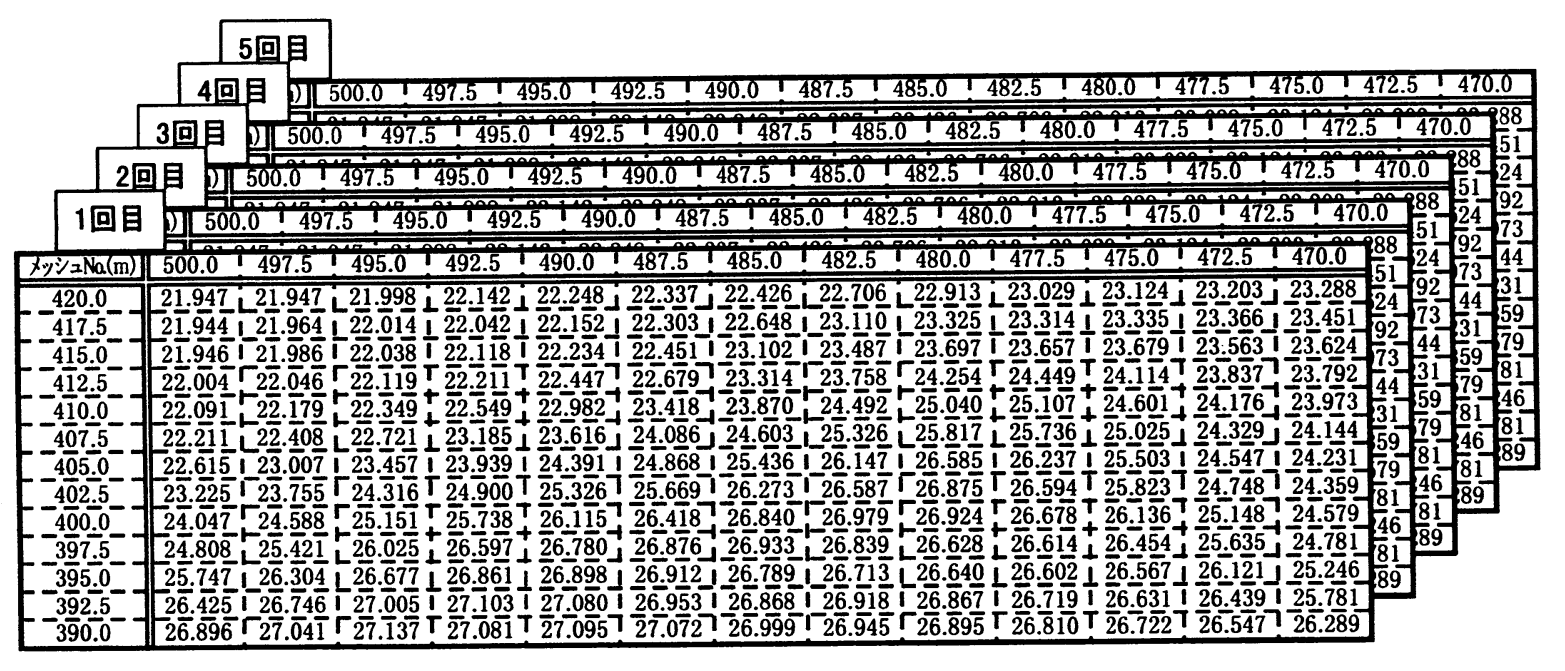

表 3.3.2 メッシュ各点での $3 \sigma$ (GPS 1 基)

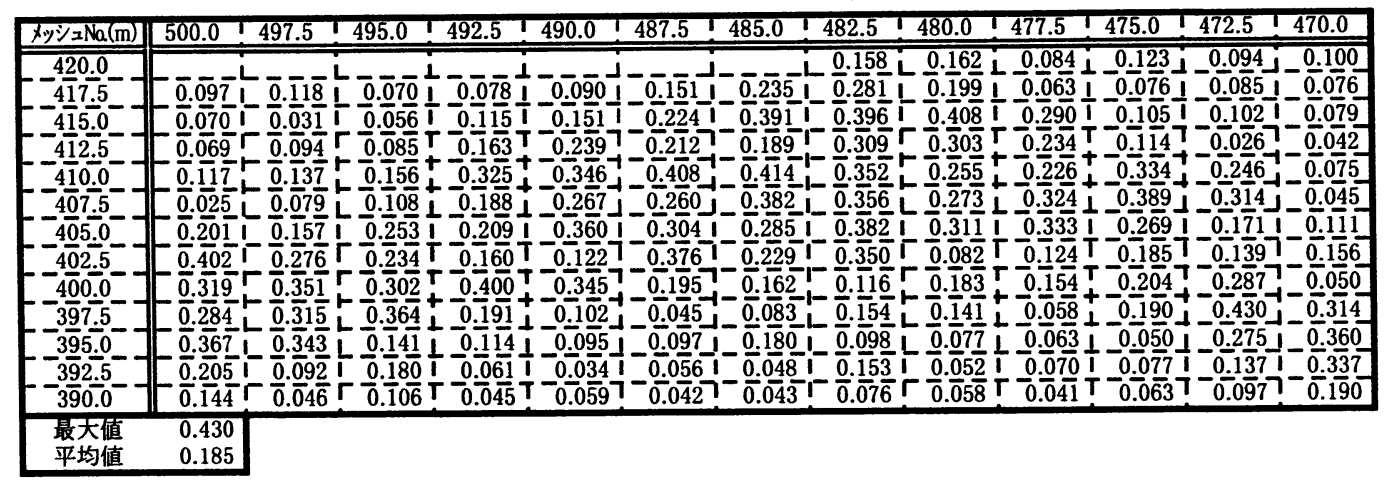

表 3.3.2 メッシュ各点での $3 \sigma$ (GPS 3 基)

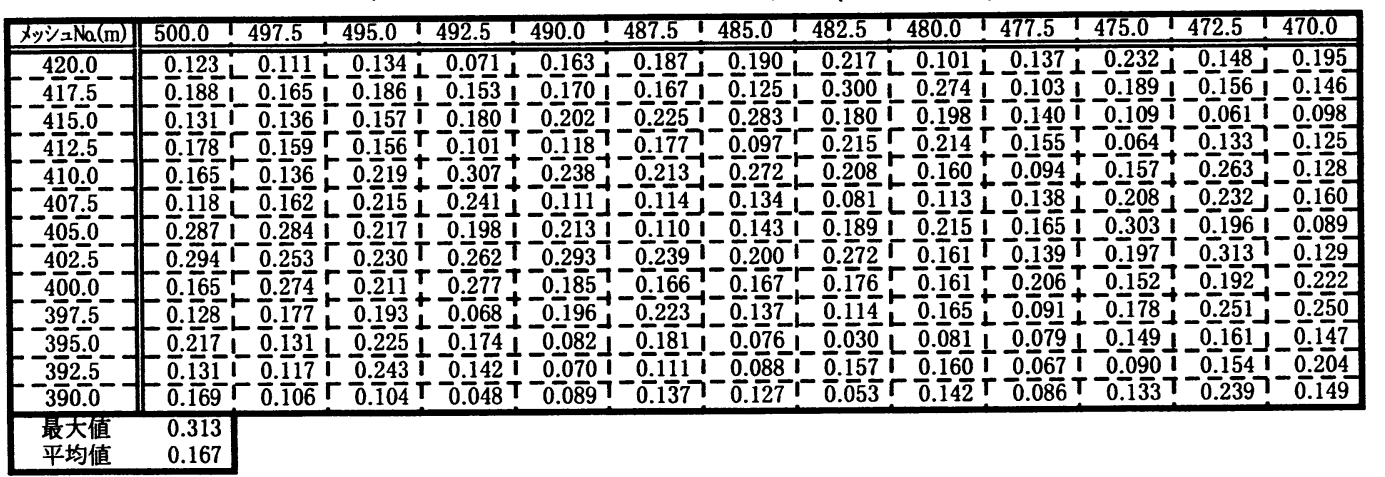

付誤差以上に動摇による測定誤差が発生すると予想されるが、GPS 3 基では傾斜・動摇による測定誤差は発生し ないため、波浪が厳しい海洋においても高い精度が期待される。

\section{4.まとめ}

海洋工事における構造物の位置誘導や海底地形の測量を、高精度かつ大幅に省力化・効率化することを目指し、 RTK-GPS 3 基を用いた測位対象物の傾斜・動摇を考虑できるシステムを開発した。開発したシステムは、その基 本性能および現場適用性を検証するため、香川県府中湖浚渫工事において検証実験を行った。実験では GPS 1 基 による測量と、傾斜・動摇を考慮できる GPS 3 基を用いた測量との精度比較を行い、本システムの高精度化を検 証した。以下にその検証実験結果をまとめる。

(1) GPS 1 基に比べ、動摇を考慮できる GPS 3 基による方法では測量精度が 30\%以上向上した。

(2) 特に海底地形の急峻部での精度が飛躍的に向上する。

(3) 波浪の小さい湖においても上記性能が確認されたため、動摇が激しい海洋においては、さらに高い精度改善 効果が期待できる。また、従来方法では波浪条件により精度低下が懸念されるため、高波浪状態では測量不 


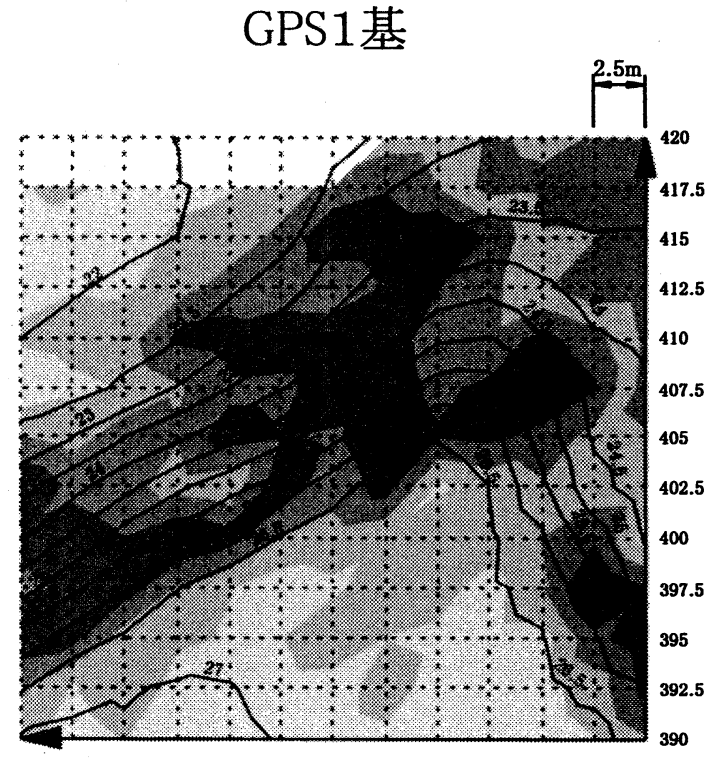

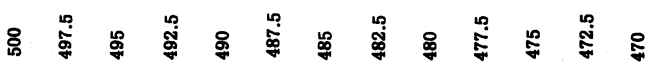

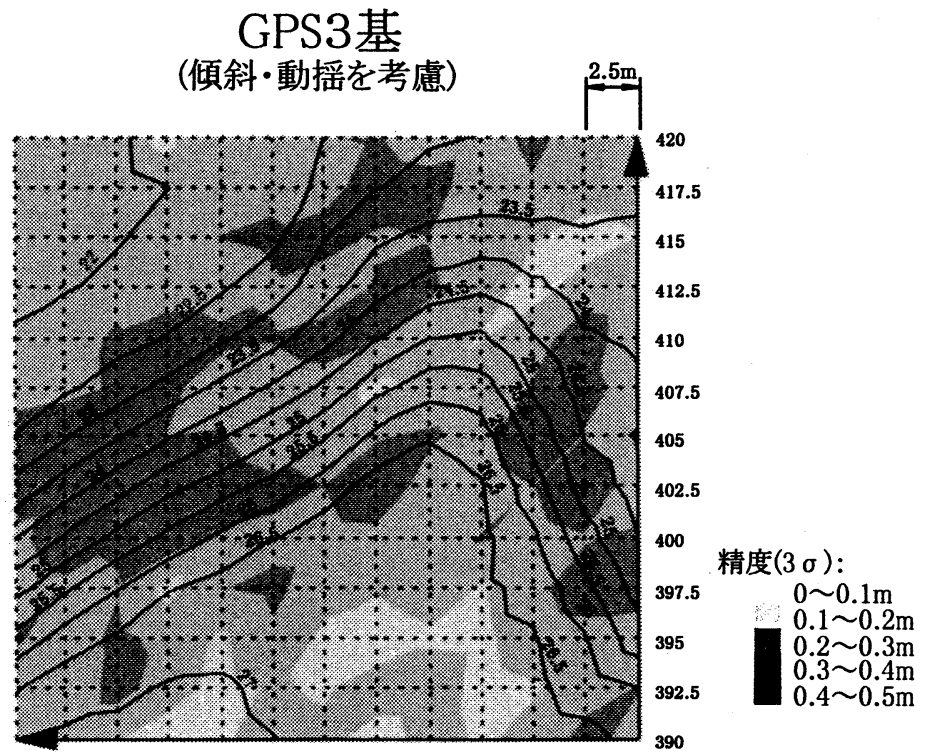

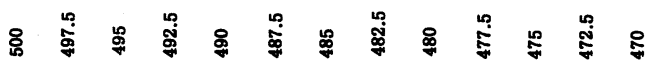

図 3.3.1 精度分布

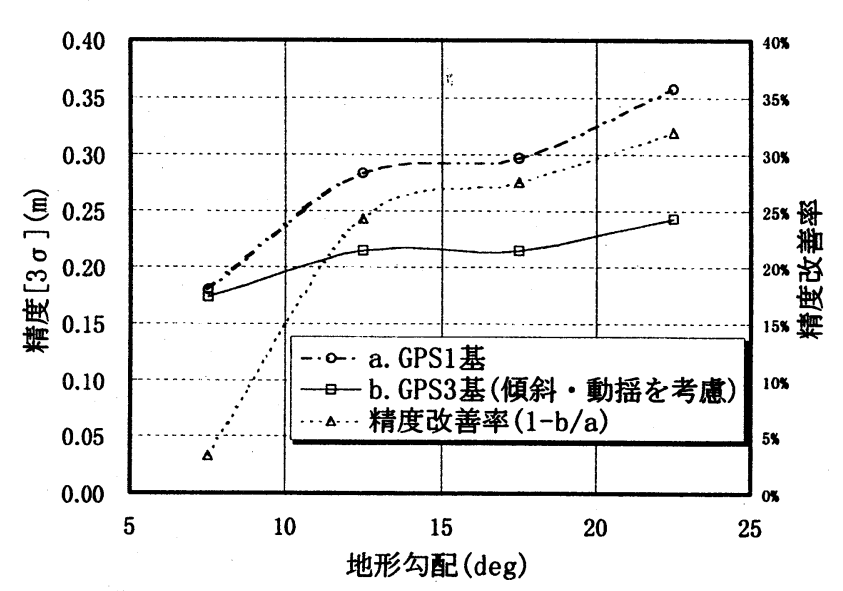

図 3.3.2 地形勾配による精度

可能であったが、本方式では波浪条件は特定できな いが測量船が航行可能な限り測量も可能となり、施 工管理の効率化ひいては工期短縮等に寄与できると 思われる。

また本論では触れていないが、現場適用性についても以 下の性能が確認されており、実施工への適用へも十分満足 する性能があることが実証された。

(4)測量時の作業員は操船者およびシステムオペレータ の 2 人で済み、省力化が確認できた。

(5)広域測量実験では、工事対象水域 $3,000 \mathrm{~m}^{2}$ を 2 時間程 度の短時間かつ高精度に測量ができた。

(6)等水深線図・断面図や土量計算等の煩雑な後処理が、

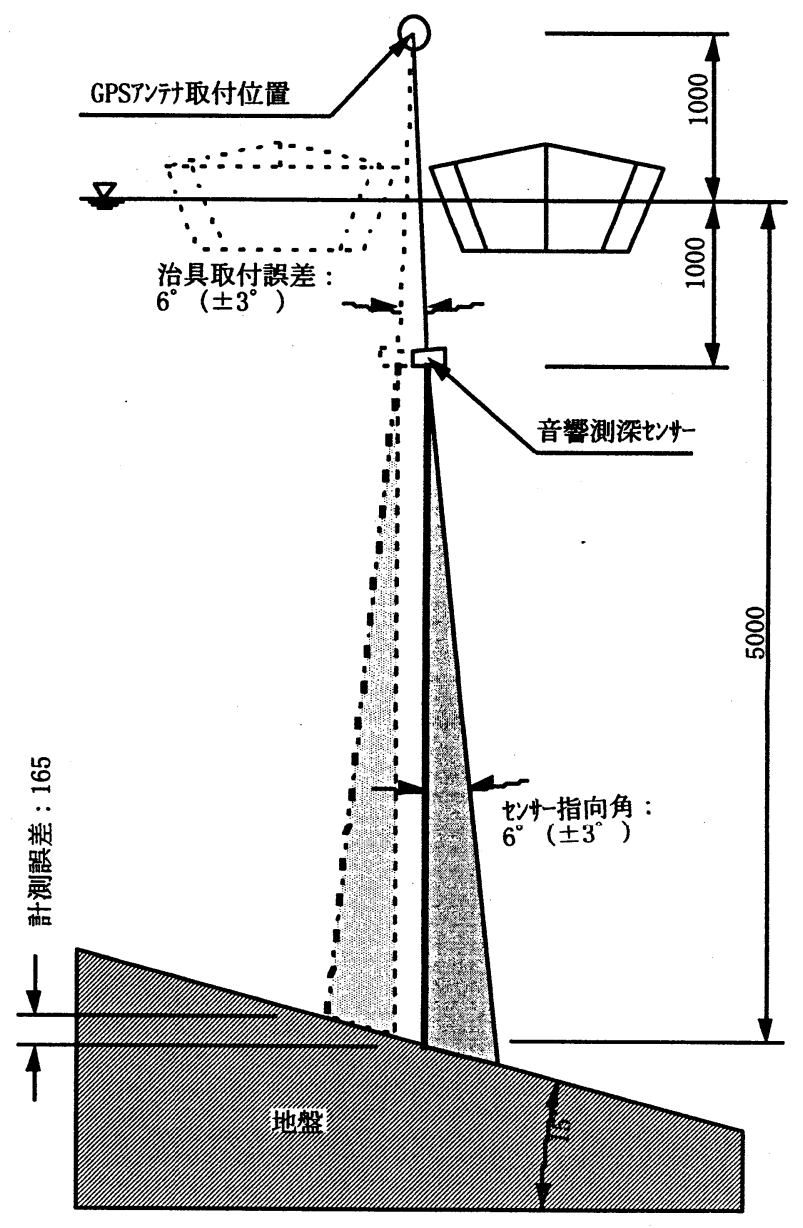

図 3.3.3 治具取付誤差による計測誤差

解析システムにより迅速かつ容易に行うことが可能であった。

これにより現場適用性も実証され、今後は海洋工事の実施工へ積極的に適用し、施工管理の省力化・効率化・高 精度化に寄与できるものと思われる。 